\title{
Hungary Is on the Path to Convergence*
}

\author{
György Matolcsy - Dániel Palotai
}

After 2010, Hungary achieved exceptional economic results both by Hungarian and international standards, and thus the Hungarian economy has become one of the growth engines of the European Union. Hungary's economic policy measures successfully placed the country on the path to convergence, bringing the country to the forefront of the European Union in areas such as raising the employment rate, decreasing unemployment, improving the budget balance and government debt, and restoring external equilibrium. As a result of this, the Hungarian economy has sufficient stability and reserves to implement a turnaround in competitiveness, which may be achieved by targeted measures. This paper reviews Hungary's macroeconomic achievements that are outstanding also by international standards and based on which sustainable convergence of the national economy can be ensured.

Journal of Economic Literature (JEL) codes: E52, E61, E62, O10, O23, O47

Keywords: convergence, sustainability, economic policy, competitiveness

\section{Introduction}

Hungary is undergoing a period of convergence that is unique in the economic history. Thanks to the successful economic policy reforms, the growth period has lasted since 2013, while simultaneously maintaining macro financial equilibrium and a gradual decline in the vulnerability of the economy. In addition to these achievements, it has once again become a realistic opportunity for Hungary to converge to Europe's more economically advanced countries in the foreseeable future.

However, convergence is not a done deal. It requires a steady commitment to continuing the policy of competitiveness reforms (Palotai - Virág 2016). The significance of focused economic policy is also confirmed by international experiences, since in international economic history successful convergence is rather

\footnotetext{
* The papers in this issue contain the views of the authors which are not necessarily the same as the official views of the Magyar Nemzeti Bank.

György Matolcsy is the Governor of the Magyar Nemzeti Bank.

Dániel Palotai is Executive Director and Chief Economist at the Magyar Nemzeti Bank.

E-mail: palotaid@mnb.hu

The authors wish to thank Gergely Baksay, Péter Gábriel and Lajos Szabó for their contribution to this paper.

The Hungarian manuscript was received on 24 June 2019.

DOI: http://doi.org/10.33893/FER.18.3.528
} 
the exception. Most convergence attempts lost momentum, and convergence often reversed. In fact, this is not surprising since during the convergence process newer and newer growth opportunities that may serve as the next step in convergence must be identified on a continuous basis. This is feasible only on the basis of a committed, creative and innovative economy policy which enjoys wide-ranging support of the society.

Starting from 2010, the Hungarian government established the conditions for convergence with measures built on each other and mutually strengthening each other's effects. It pursued a drastically new crisis management approach and restored equilibrium by supporting growth. It reformed the tax regime to foster employment and stabilised the budget. Harmonisation of fiscal and monetary policy from 2013 onwards was another step forward. The central bank supported economic growth and helped restart lending by way of new, innovative programmes, while at the same time also reducing the vulnerability of the economy.

As the post-2010 reforms started bearing fruits, Hungary embarked on an equilibrium growth path in 2013. Hungarian GDP has been growing dynamically for many years, rising faster than the average of the developed countries. Meanwhile, the low budget deficit, the downward trend in government debt, the trade surplus and moderate inflation were also maintained. Low unemployment and dynamic wage increases make the results of growth tangible for wide layers of Hungarian society. The period of growth and equilibrium seen since 2013 is unprecedented in the history of the modern Hungarian economy. However, economic convergence to the developed countries requires even more. Convergence is conditional on maintaining the growth period for more than a decade, during which time additional growth reserves must be activated, i.e. a turnaround in competitiveness must be achieved.

The primary objective of this paper is to present the main achievements of the current convergence process. The measures supporting the realisation of results have already been presented in detail in previous papers (see, for example, MNB $2017 a$ and Matolcsy - Palotai 2018), and thus we describe those here only to the degree necessary for evaluating the results. The paper is structured as follows: First we depict the baseline, i.e. the situation of the Hungarian economy right before the outbreak and after the global financial crisis. We then shortly present the reforms that the government used to manage the crisis after 2010 and that created the basis for economic growth and financial equilibrium. Following this, we move on to the analysis of the results already achieved during the convergence period, which we also assess compared to the performance of the European countries. 


\section{Economic policy errors before and during the crisis}

The global financial crisis ruthlessly highlighted the fact that permanent convergence is possible only if macro financial stability is maintained. In the 2000s, the erroneous Hungarian economic policy fostered growth at the sacrifice of equilibrium. As a result of this, Hungary was hit particularly hard by the global financial crisis.

Prior to the crisis, fiscal policy was irresponsibly loose, and the indebtedness of the private sector also rose continuously. The government deficit of 8 per cent on average between 2002 and 2006, and the net external borrowing requirement of 8 per cent on average, were not sustainable in the long run (Figure 1). The degree of labour taxes was extremely high by international standards, as a result of which - in conjunction with the looser-than-justified social benefits, which did not foster employment - by 2007 Hungary's rates of employment and labour force participation were among the lowest in Europe. It was not possible to finance the high government debt with domestic funds (Matolcsy 2008). The increasing share of non-residents in the financing of the government debt increased Hungary's vulnerability and raised the funding costs of the state, and indirectly of the private sector.

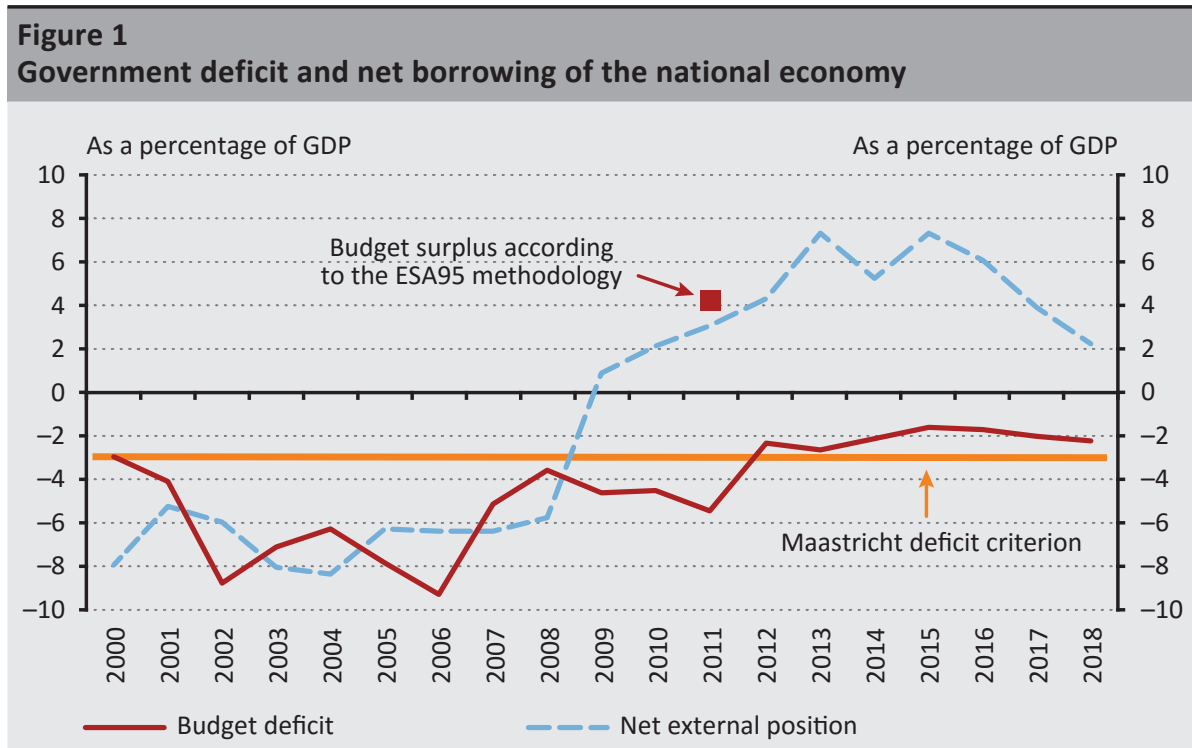


Government overspending and private sector indebtedness led to inflation exceeding the central bank's target. Monetary policy attempted to contain inflation by maintaining a high nominal interest rate (Figure 2). However, with the permanently expansionary fiscal policy this yielded no success; moreover, the high nominal interest rates led to further deterioration in the general government balance via the rise in interest expenses (Matolcsy - Palotai 2016). In addition, high interest rates led to the spread of foreign currency loans. As a result of inaction by the financial regulatory authorities, there was a surge in foreign currency lending to households, which had commenced in 2003, and at the time of the outbreak of the financial crisis, the majority of outstanding housing loans were already denominated in foreign currency (Lentner 2015). The increase in foreign currency exposure rendered the economy extremely vulnerable to changes in the international financial market environment. By 2006, growth financed by indebtedness became unsustainable. The government tried to reduce the government deficit by fiscal austerity measures. However, authority measures curbed growth, and thus the convergence of the Hungarian economy came to a halt and, in the absence of growth, the anticipated balance improvement also failed to materialise.

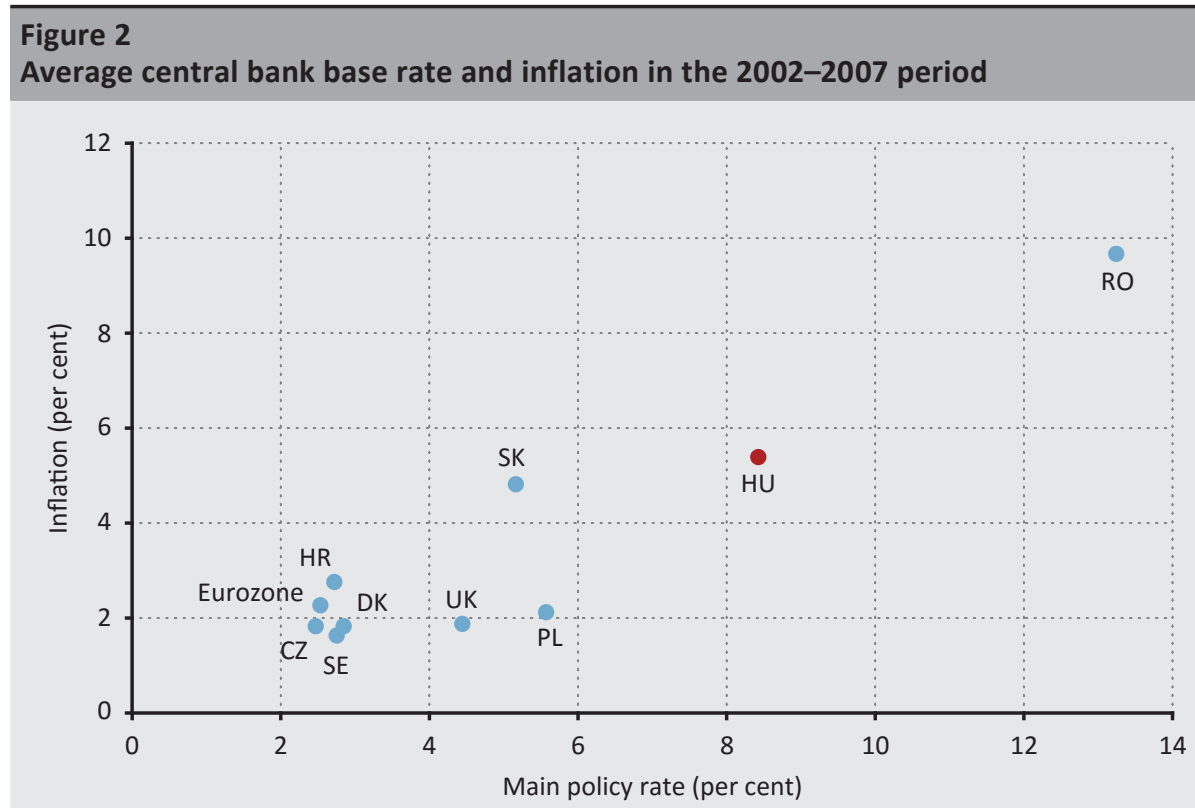

Source: BIS, Eurostat 
On the whole, the vulnerability that built up before the financial crisis and crisis management based on authority measures caused the Hungarian economy to suffer one of the largest declines in Europe in the years that followed the outbreak of the financial crisis. As a result of the high government debt and the continued substantial government deficit, there was no room for fiscal easing, which could have mitigated the economic downturn. Upon the outbreak of the crisis, the global decline in investors' risk appetite and the shaken confidence resulted in liquidity constraints on the international financial markets. Investors turned to safe assets, which made the financing of the Hungarian budget extremely complicated. In parallel with the problems of financing the government debt, the stability of the financial intermediary system also wavered. The gradually realised and expected lending losses made commercial banks to curb their lending activities, which further deepened the crisis. Naturally, the deteriorating mortgage loan portfolios caused problems not only for the financial sector. The increasing risk of the loss of homes raised the threat of a severe social crisis. Due to the inability to finance government debt from the market, the government at that time turned to the EU and IMF for a financial rescue package. However, the rescue package was conditional on the implementation of additional austerity measures, which further deepened the crisis.

\section{Successful crisis management after $\mathbf{2 0 1 0}$}

After 2010, the new government broke with the previous crisis management practice and placed the emphasis on the stimulation of the economy, instead of authority measures. One of the main growth-friendly ways to contain the budget deficit was to stimulate employment. As a result of the tax reform, the structure of tax revenues changed in a growth-friendly way: the weight of labour taxes decreased (Svraka et al. 2014), while that of consumption taxes rose. The flat rate personal income tax regime was introduced, as a result of which the marginal tax rate on labour substantially decreased (Giday - Mádi 2018). In addition to the tax cuts, a significant contribution to boosting employment also came from the reduction of social benefits that were not conducive to employment, and public employment supplemented with education programmes and the substantial increase in family support elements (conditional on employment) also needed. Growth in labour demand was additionally supported by the reduction and simplification of the taxes payable by small enterprises. The purpose of the Job Protection Action Plan was to support those in the most disadvantaged labour market position. In addition to stimulating employment, the introduction of sector specific taxes and the reform of the pension system also materially improved the budget balance. The measures 
aimed at fiscal stabilisation proved to be successful, and thus the excessive deficit procedure (EDP) conducted by the EU against Hungary was lifted in 2013. This is all the more a major achievement, because after 9 years of EDP the suspension of EU funds was a real risk.

Harmonisation of fiscal and monetary policies was essential to set the economy on a growth path (Matolcsy - Palotai 2016). From 2013, monetary policy played a much more active role than previously in fostering economic growth, in addition to its primary objective, i.e. ensuring price stability. Owing to the gradual cuts in the base rate, the private sector's cost of finance decreased, while investment and consumption picked up. The decreasing base rate and the central bank programmes reduced government securities market yields and also substantially lowered the interest expenses of the budget (Kicsák 2019). The expansion of the central bank's set of monetary policy instruments with new, innovative elements was instrumental in the transformation of Hungarian monetary policy.

The Magyar Nemzeti Bank (the central bank of Hungary, MNB) launched a number of new, targeted programmes to strengthen financial stability and stimulate economic growth. In the first three phases of the Funding for Growth Scheme (FGS), the MNB provided the SME sector with financing in the amount of HUF 2,800 billion via the banking sector. The purpose of the scheme was to restart corporate lending, which had declined to an extreme degree as a result of deleveraging by commercial banks after the crisis (Bokor et al. 2014). Commercial banks, utilising the interest-free central bank funding, could grant loans at a maximum interest rate of 2.5 per cent to the SME sector for new investments, current assets, pre-financing of EU funds and refinancing of foreign currency loans. By easing lending constraints and boosting investments, the scheme raised GDP by 2-2.5 percentage points between 2013 and 2017 (Fábián - Pulai 2018).

The phasing-out of foreign currency loans was of outstanding importance to strengthen financial stability. In the period 2011-2012, the government reduced the burdens of households by the early repayment scheme. After the adoption of the Curia's uniformity decision, underlying the conversion of foreign currency loans, the MNB provided banks with funding of EUR 9.7 billion in total, for the implementation of the forint conversion (Kolozsi 2018). In addition to relieving Hungary of a severe financial stability risk, the forint conversion, which was implemented in an orderly manner in a single step, also increased the efficiency of monetary transmission. The timing of the measure was extremely favourable, since soon afterwards the Swiss central bank abandoned its minimum exchange rate for Swiss franc, which resulted in significant depreciation of the forint exchange rate to the Swiss franc (for more details, see Fábián - Zágonyi 2015; Nagy 2015). 
Owing to the fiscal and monetary turnaround, the period of active crisis management ended and balance was restored, and thereafter the focus of economic policy shifted to the support of sustainable convergence.

\section{Achievements of the convergence of the Hungarian economy (2013-)}

Since the growth turnaround in 2013, the economy has been on a convergence path. The condition for successful economic convergence is that economic growth should markedly exceed that of the benchmark countries. Between 2013 and 2018, Hungary's GDP rose by 23 per cent in total, i.e. considerably faster than the output of the more advanced Western European countries. For example, in four of these six years, growth in the Hungarian economy exceeded the annual growth of Austria by more than 2 per cent. Hungary's economic convergence is reflected more directly by the change in the GDP per capita ratio, as the most common index of economic development. Between 2013 and 2018, GDP per capita in Hungary rose by almost 20 per cent, i.e. at a faster rate than in the large economies of the EU, in the Mediterranean countries or in Scandinavia, and at a similar rate as in the Visegrád countries $^{1}$, regarded as the growth engine of the EU (Figure 3).

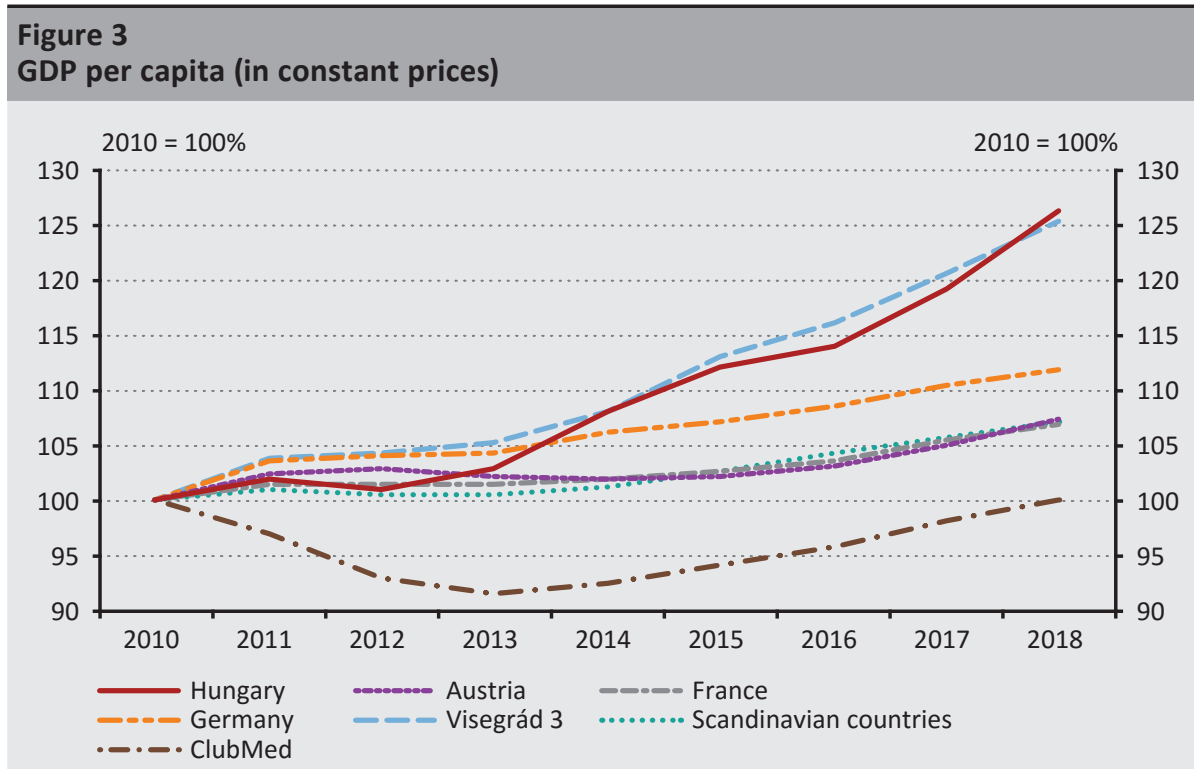

Note: The members of the Visegrád 3 (V3 Group) are the Czech Republic, Poland and Slovakia, the Scandinavian countries include Denmark, Finland and Sweden, while the ClubMed group includes Greece, Italy, Portugal and Spain.

Source: Eurostat

\footnotetext{
${ }^{1}$ Visegrád Group includes the Czech Republic, Hungary, Poland and Slovakia.
} 
Also considering the financing structure of the Hungarian economy, the growth period lasting since 2013 is unprecedented in the history of the Hungarian economy. Previous growth periods for the Hungarian economy were characterised by external indebtedness, constituting a striking contrast to the current dynamic economic growth, realised in conjunction with a steady current account surplus and a low budget deficit (Figure 4).

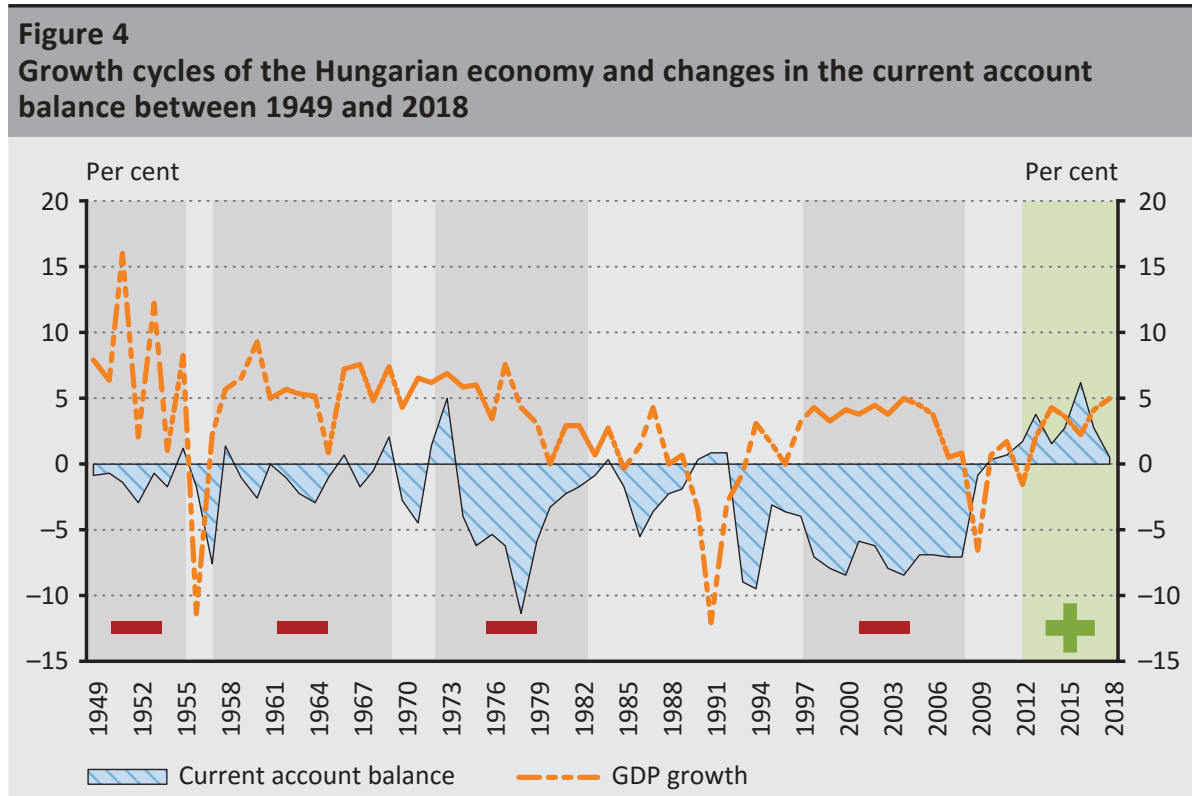

Note: The coloured stripes indicate the longer periods of boom, while the signs in the figure show the current account balance in the respective period.

Source: Lehmann (2019)

It is worth assessing Hungary's growth performance since 2013 from a broader perspective as well. Based on the data from the period 1920-2016, Figure 5 shows how many years growth in any country was able to outstrip the growth of the global economy. Past experiences show that individual states were usually able to maintain a growth rate higher than that of the global economy only for 1-2 years. The ratio of growth periods that steadily exceeded global economic growth and were longer than that of the current growth period of the Hungarian economy, which has already lasted for 7 years is merely 6 per cent. 
The successful convergence experiences of the $20^{\text {th }}$ century indicate that convergence takes at least one decade. Accordingly, Hungary - if it wants to break out of the middle income trap - also needs to prolong the current growth period for much longer than a decade. In the past fifty years, only a few economies were able to achieve this: e.g. South Korea (Yoo 2008) and Singapore (Kaushik 2012) among the Southeast Asian countries (Krugman 1994; Felipe 2006), while among the Western European countries, among others, Austria (Prammer 2004) and Ireland (Powell 2003).

\section{Figure 5}

Distribution of the length of growth periods steadily exceeding the average growth of the global economy (between 1920 and 2016)

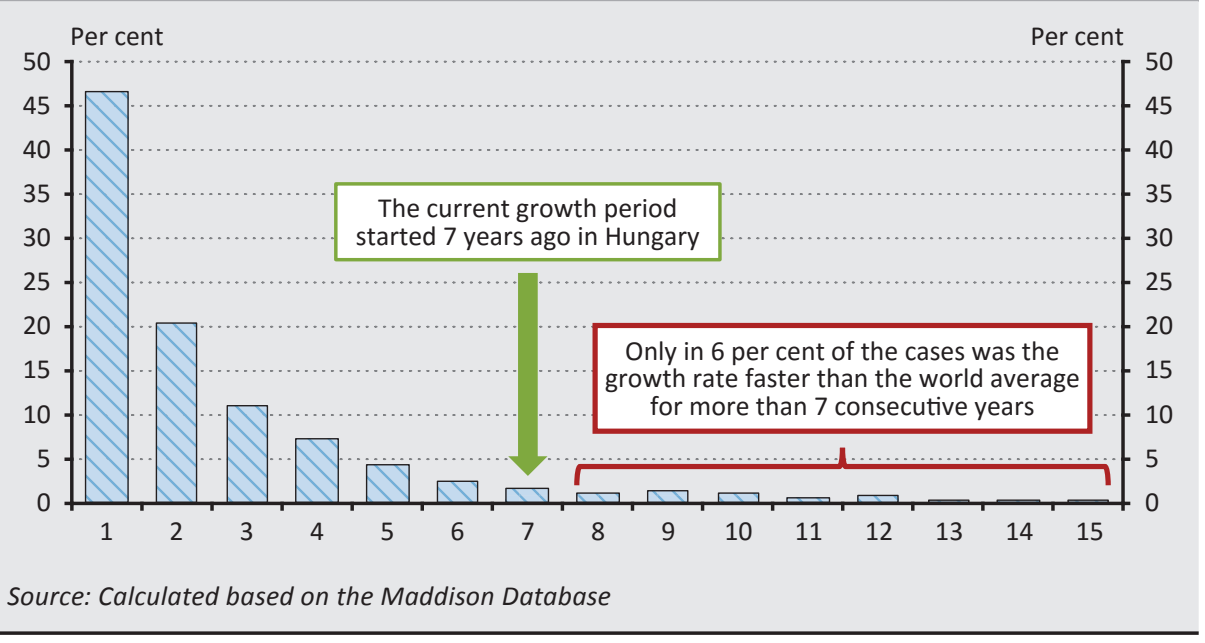

In the following, we examine several aspects of the convergence process, reflected both in economic growth and stability, where the causes and consequences are often intertwined. Presumably, none of the factors on its own would have been capable of achieving material and sustainable progress without development in other areas. Hence, it is difficult to determine the sequence of effects, but in our opinion growth in employment is the most important factor, and thus we start the chain of thoughts with that.

In recent years, the most important basis of economic growth was the rise in employment. In 2010, the new government believed that it was simultaneously possible to achieve economic growth and equilibrium by raising employment, and thus reforms were launched both of the tax regime (primarily by introducing the flat rate personal income tax) and the social benefit system in a way to stimulate 
employment to the greatest possible degree. The results are clearly visible. Between 2011 and 2018, the number of employees in Hungary rose by 750,000 and reached 4.5 million in 2019. As a result, the Hungarian employment rate - which was the lowest in the EU in 2010 - already reached the average of the EU and exceeds the level recorded in France and Ireland (Figure 6).

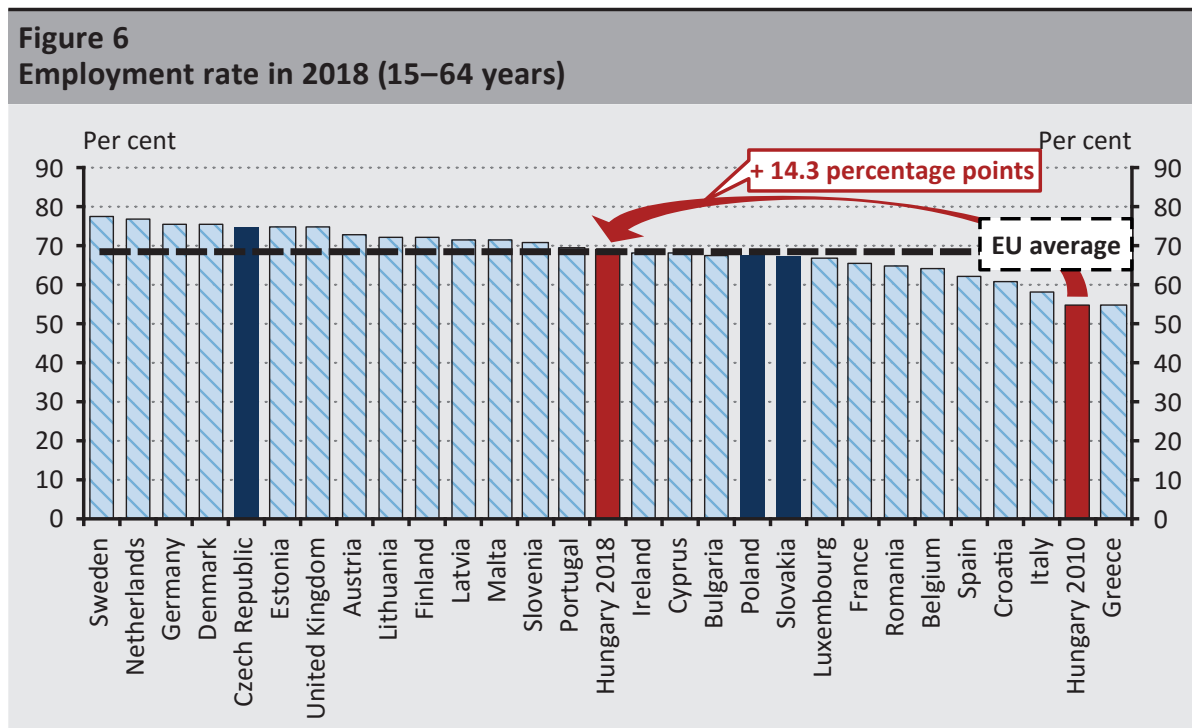

Source: Eurostat

In parallel with the rise in employment, the number of unemployed persons also fell substantially, and thus Hungary made an important step towards achieving full employment. In 2018, the ratio of unemployed persons was 3.7 per cent, which was the third lowest figure in the European Union. The unemployment rate was lower only in Germany and in the Czech Republic, while in all other more advanced EU Member States the unemployment rate exceeds that of Hungary. There was a particularly large decrease in Hungary in the unemployment of young people. Their unemployment ratio fell from the pre-crisis level of 25 per cent to 10 per cent (Figure 7), which was strongly attributable to the measures of the Job Protection Action Plan fostering the employment of people below the age of 25 . 


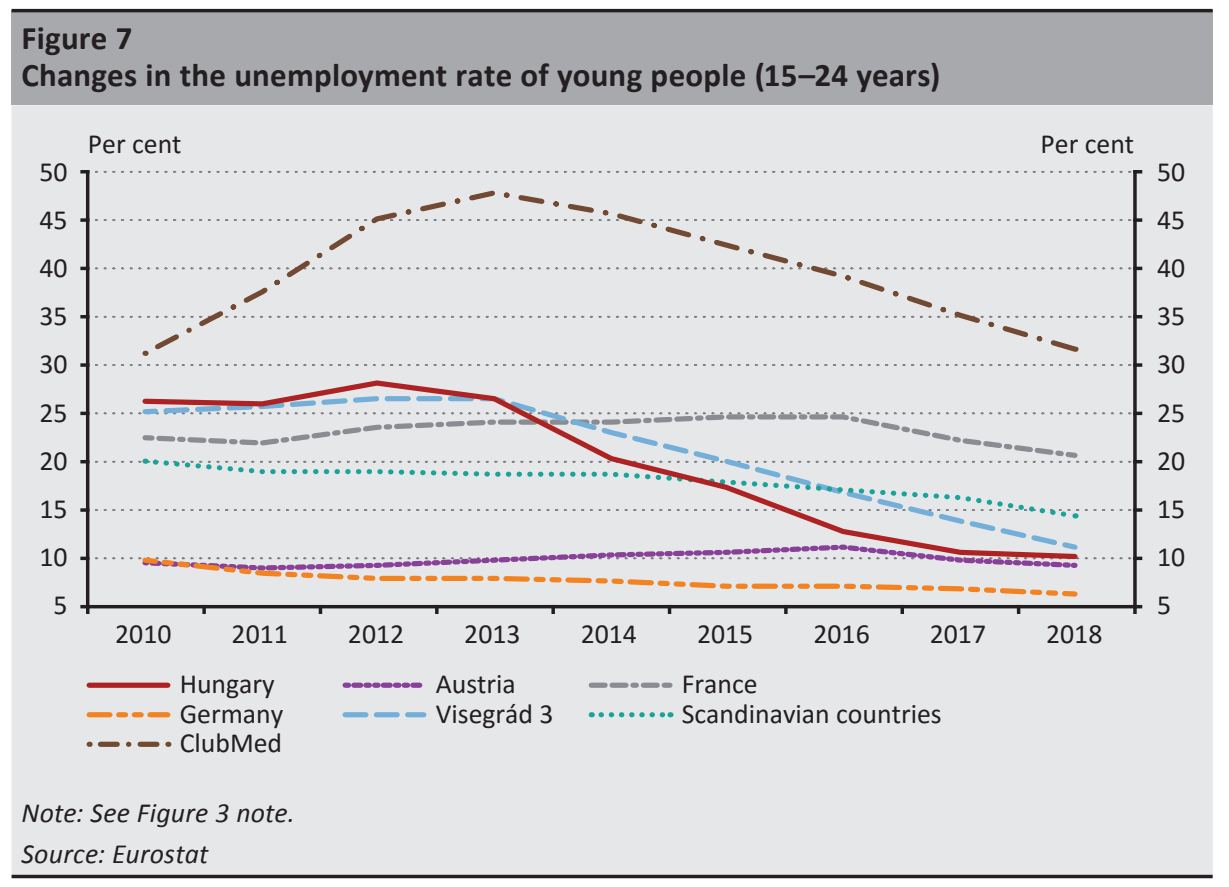

Rising employment rate is key to successful economic convergence, but it also means that there are constraints of further growth in employment. There are still labour reserves in certain social groups of the Hungarian economy, but they are significant smaller than before. Accordingly, economic growth may still primarily stem from the increase in labour productivity, as well as the flow of labour force to jobs of higher productivity. All of this requires investments, technological development and continuously adjusting the economic structure.

As regards employees, the rise in real wages is also a sign of the convergence process, in addition to the growth in employment. The rise in wages affected a broad range of employees under a tightening labour market. The raising of minimum wages made a substantial contribution to the wage increase of those with low earned income: the amount of the lowest wage payable to full-time employees doubled between 2010 and 2019. The growth in the purchasing power of wages was also supported by inflation anchored for years. The growth rate of real wages was dynamic not only compared to that of the Western European countries, but it also outperformed the average growth rate registered by the other Visegrád countries (Figure 8). However, the dynamic rise in wages did not jeopardise the competitiveness of the economy, since the wage share reached its historic average only in recent years (Balatoni - Erdélyi 2018). 


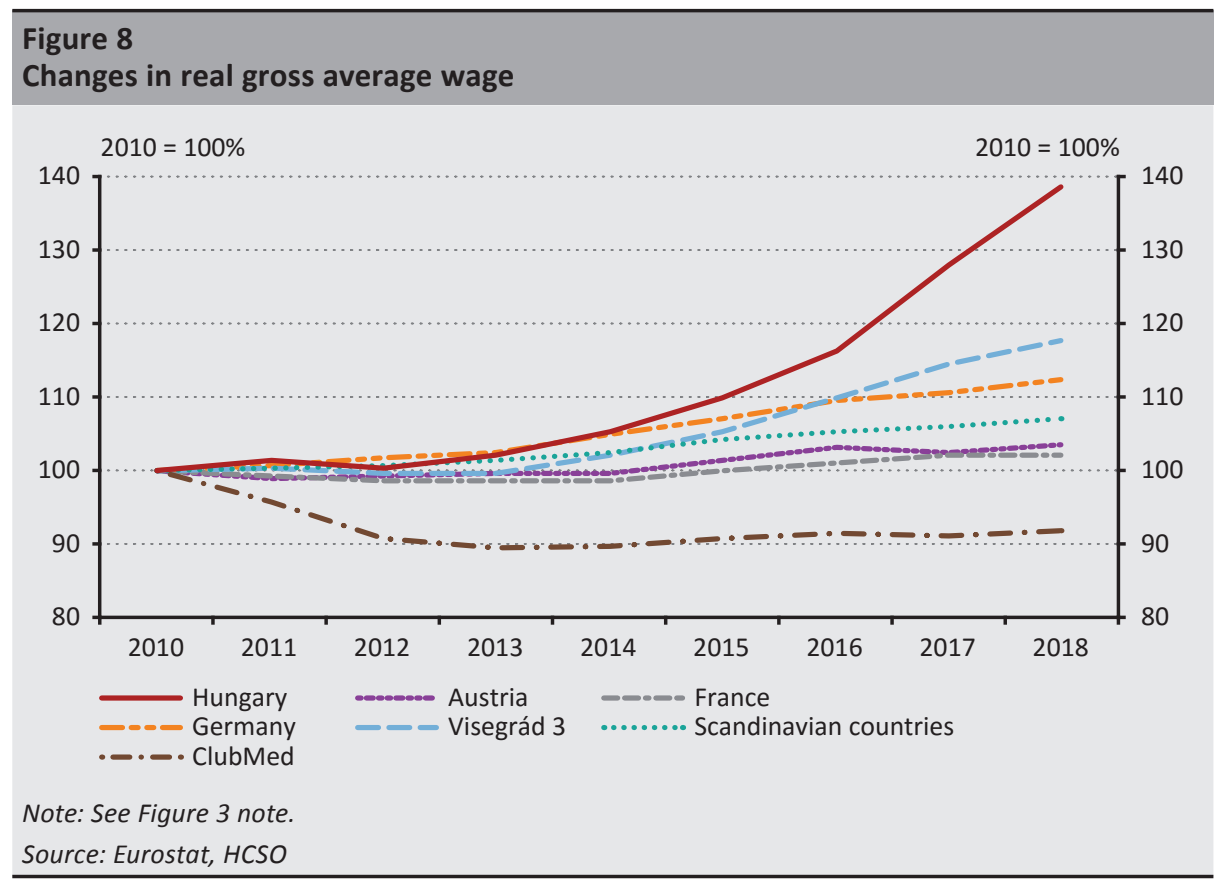

The growth in earnings also generated a turnaround in household consumption. During the crisis, the consumption of Hungarian households declined to an extremely large degree (Figure 9) even in an international comparison, due to the increased instalments and the fiscal austerity measures: by 2010 consumption had fallen to the level of the early 2000s in real terms. However, starting with the growth turnaround in 2013, owing to the rising employment and real wages, the consumption expenditure of households increased at an accelerating rate, expanding by more than 5 per cent in 2018. Thus, Hungary is in the vanguard of the European Union in this respect as well. The rise in consumption exceeded not only that registered in the most developed Member States, but also rose compared to the average of the Visegrád countries, which exhibit similarly dynamic GDP growth. Thus, the shift in the tax regime's focus to consumption and sales taxes did not curb consumption, but increased budget revenues to an even larger degree. 


\section{Figure 9}

Changes in consumption in the European Union and in Hungary (annual average changes)

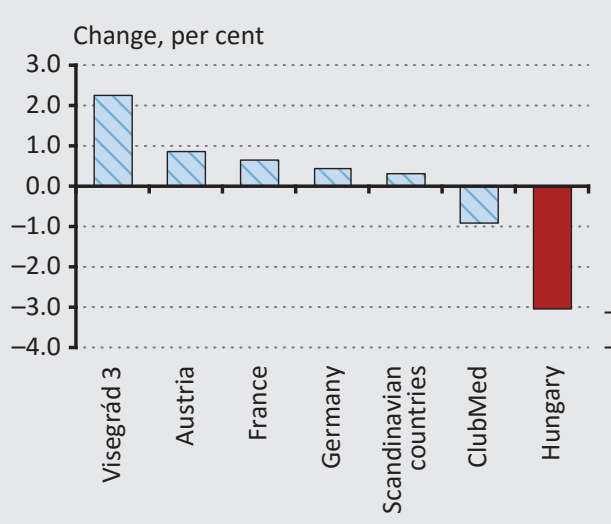

2008-2010

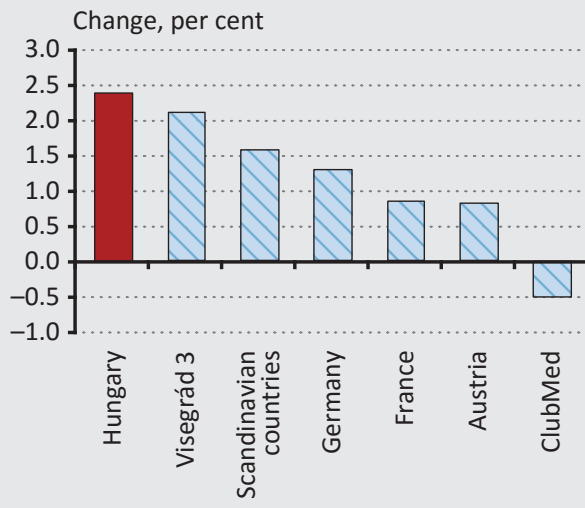

2011-2018

Note: See Figure 3 note.

Source: Eurostat

In addition to the turnaround in employment, another driver of growth was the recovery in lending. During the crisis, a credit crunch developed in Hungary, the protraction of which jeopardised the success of recovery from the crisis. The MNB launched the Funding for Growth Scheme with a view to preventing the credit crunch, which ensured lending to the SME sector that was unfavoured on the lending market, at favourable price. Meanwhile, the cuts to the base rate supported the decrease in loan prices in all sectors. Following the end of FGS, the MNB launched new schemes as well, to support SMEs' access to funding. Within the framework of the Market-based Lending Scheme, launched in autumn 2015, the MNB supports banks' willingness to lend by an instrument facilitating risk management and liquidity management. The schemes launched by the MNB in 2019 - i.e. the FGS Fix and the Bond Funding for Growth Scheme - intend to exert an effect primarily on the corporate funding structure, with the goal of increasing the share of long-term and fixed-rate forms of funding.

The central bank schemes and the improved economic prospects resulted in a successful lending turnaround (Figure 10). The growth of over 10 per cent in corporate lending in 2017 and 2018 was extremely dynamic in a European comparison, while some of the Mediterranean countries, where crisis management failed, are still characterised by declining lending. The growth in lending also indicates that corporations have confidence in sustained growth and convergence. Whereas during the crisis the investment ratio fell below 20 per cent of GDP, 
owing to the lending turnaround, the financing facilities provided by the European Structural Funds and the growth-supporting government measures, by 2014 this value exceeded 22 per cent of GDP and rose to 25 per cent of GDP by 2018. The MNB's June 2019 Inflation report projects an investment ratio of around 28 per cent by 2019-2020, which ensures the growth and rollover of corporate assets, and thereby rising productivity.

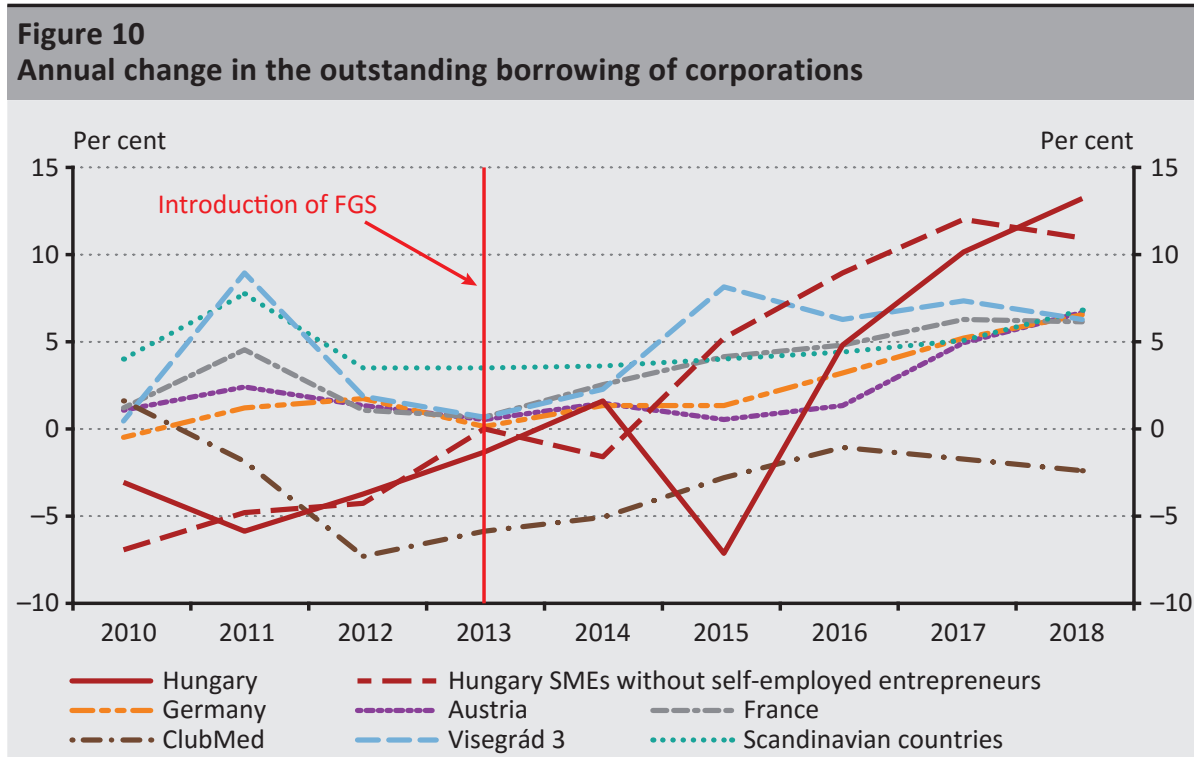

Note: The annual growth rate is the average of the quarterly growth rates. See Figure 3 note.

Source: $E C B$

The substantial reduction in the corporate income tax rate also contributed to the rise in investment activity. In addition to the labour tax cuts, the decrease in the income taxes directly burdening corporations also stimulated economic activity. The decrease in the tax burdens imposed on smaller enterprises already commenced in 2010 by extending the range of enterprises eligible for the preferential corporate income tax and later on by creating new forms of taxation targeting small enterprises (small taxpayers' itemised lump sum tax and small business tax). Since the fiscal situation permitted this, from 2017 the corporate income tax rate was uniformly reduced to 9 per cent in Hungary, which is the lowest value in the European Union (Figure 11). The reduction of the corporate income tax and labour tax rates together substantially improved Hungary's capital attraction capability, as well as the corporations' willingness to invest, their profitability and capital accumulation capacity. The more investor-friendly environment is also reflected in the employment and investment data. The international companies, including the car industry companies which is of outstanding importance for Hungarian industry, implemented several large investments in Hungary in recent years. 


\section{Figure 11}

Upper rate of the corporate income tax in 2018 (per cent)

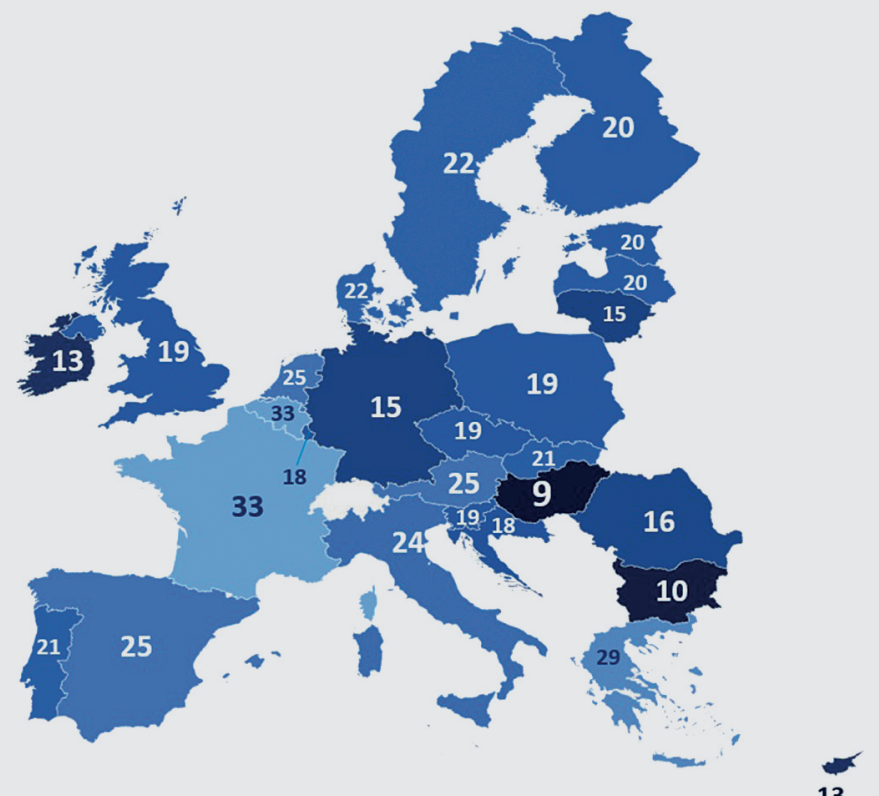

In the past years, Hungarian economic growth was also supported by the international financial environment and the expansion of Hungary's key trading partners. However, convergence may only succeed if it lasts for a sufficiently long period, and thus it also spans over periods where the external environment does not support growth. As regards the convergence of economies, recessions in the global economy and the relative performance in periods of crisis are as important as those observed in a favourable environment. International experiences show that countries lagging behind or stuck in the middle income trap are often unable to catch up due to major downturn suffered during the crises (Cerra - Saxena 2017). As a result of the underdeveloped institutional system, the absence of crisis management mechanisms, the build-up of financial risks and the weaknesses of the private sector's adaptability, the crisis hits converging countries harder than the advanced economies, and thus convergence may be quickly abolished by a crisis. 
Due to the foregoing, maintaining financial equilibrium in all sectors of the economy is an essential condition for economic convergence and long-term growth (Matolcsy 2015). This is why it was also essential for Hungary to reduce the vulnerability of the economy after the post-crisis stabilisation. Since 2010, Hungary's net lending regularly recorded a surplus. While the pre-crisis current account balance showed a substantial deficit, in the period 2012-2018 Hungary already recorded a substantial surplus (Figure 12).

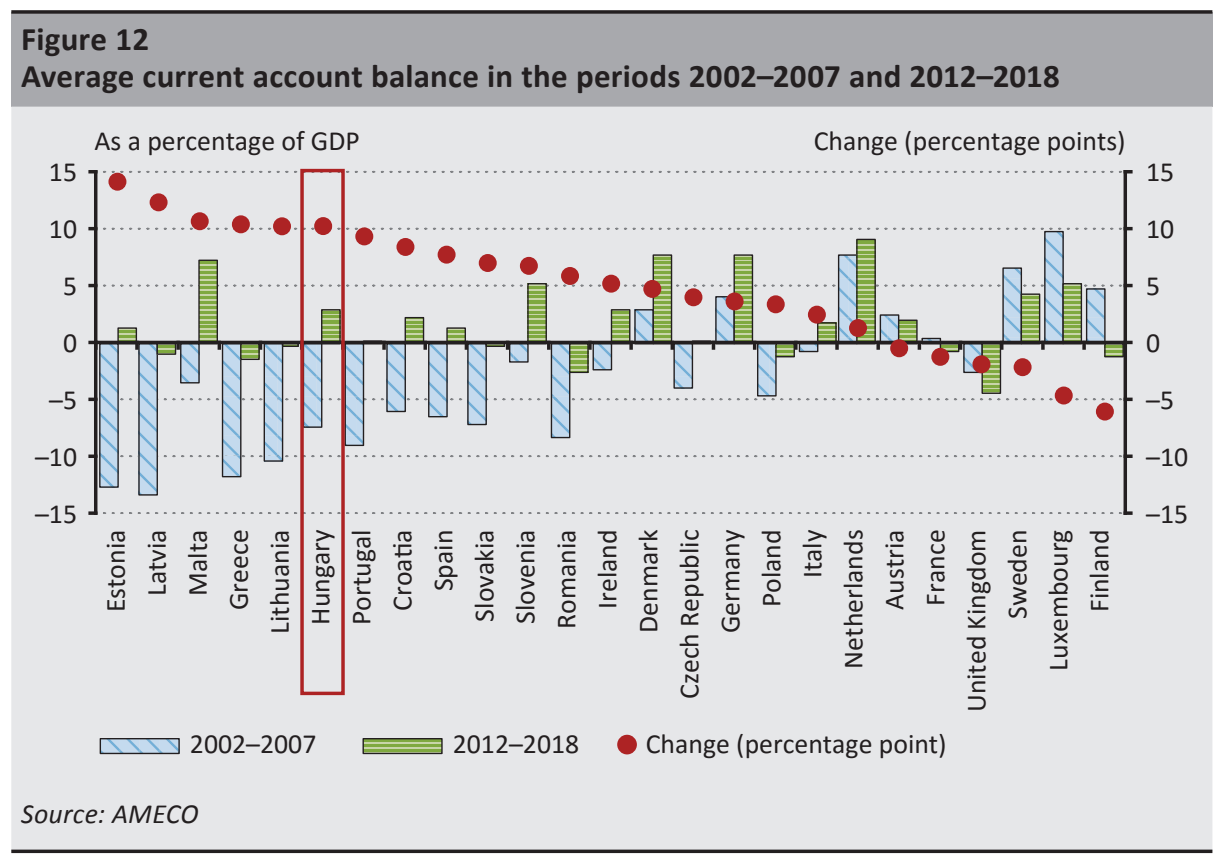

The current account surplus continually lowered Hungary's external debt, thereby reducing the country's vulnerability. Hungary's net external debt fell from 49 per cent of GDP to 5.3 per cent between 2010 and 2018 (Figure 13) and thus Hungary was on the verge of becoming a net lender. 


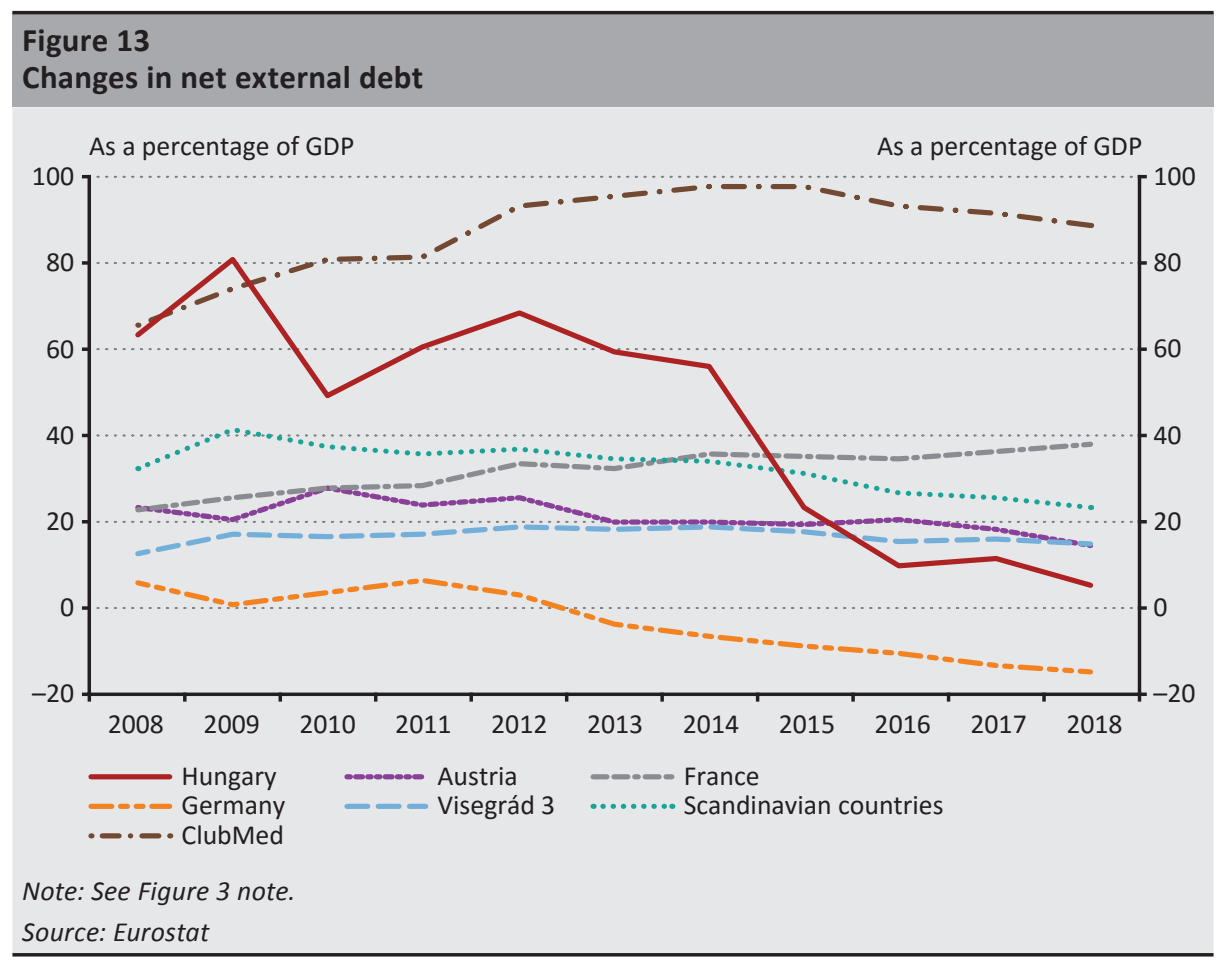

The post-2010 disciplined fiscal policy was also successful. As a result of the successful fiscal turnaround, since 2012 the budget deficit has steadily remained below the 3 per cent Maastricht threshold, at around 2 per cent. The budget balance improved to a larger degree in Hungary compared to the pre-crisis periods than anywhere else in the European Union (Figure 14). The post-2010 tax reform exerted its effect gradually, partly by boosting growth. According to the calculation of Szoboszlai et al. (2018), the tax reform, together with the transformation of transfers, improved the general government balance by roughly HUF 200 billion in the longer run. The success of the reforms is also evidenced by the fact that between 2014 and 2016 tax revenues as a percentage of GDP rose by 2 percentage points without implementing any tax increase (Palotai 2017). In addition to the tax reform, expenditure side reforms were also implemented through the Széll Kálmán Plans. The decrease in the budget deficit was also supported by the MNB's monetary policy, partly through the base rate cut, and partly through other, targeted schemes. It is also due to this that yields on government securities declined substantially, and thus the interest expenses of the budget fell from 4.3 per cent of GDP, recorded in 2012, to 2.3 per cent by 2018, representing a total saving of HUF 2,400 billion for the budget in this period. 


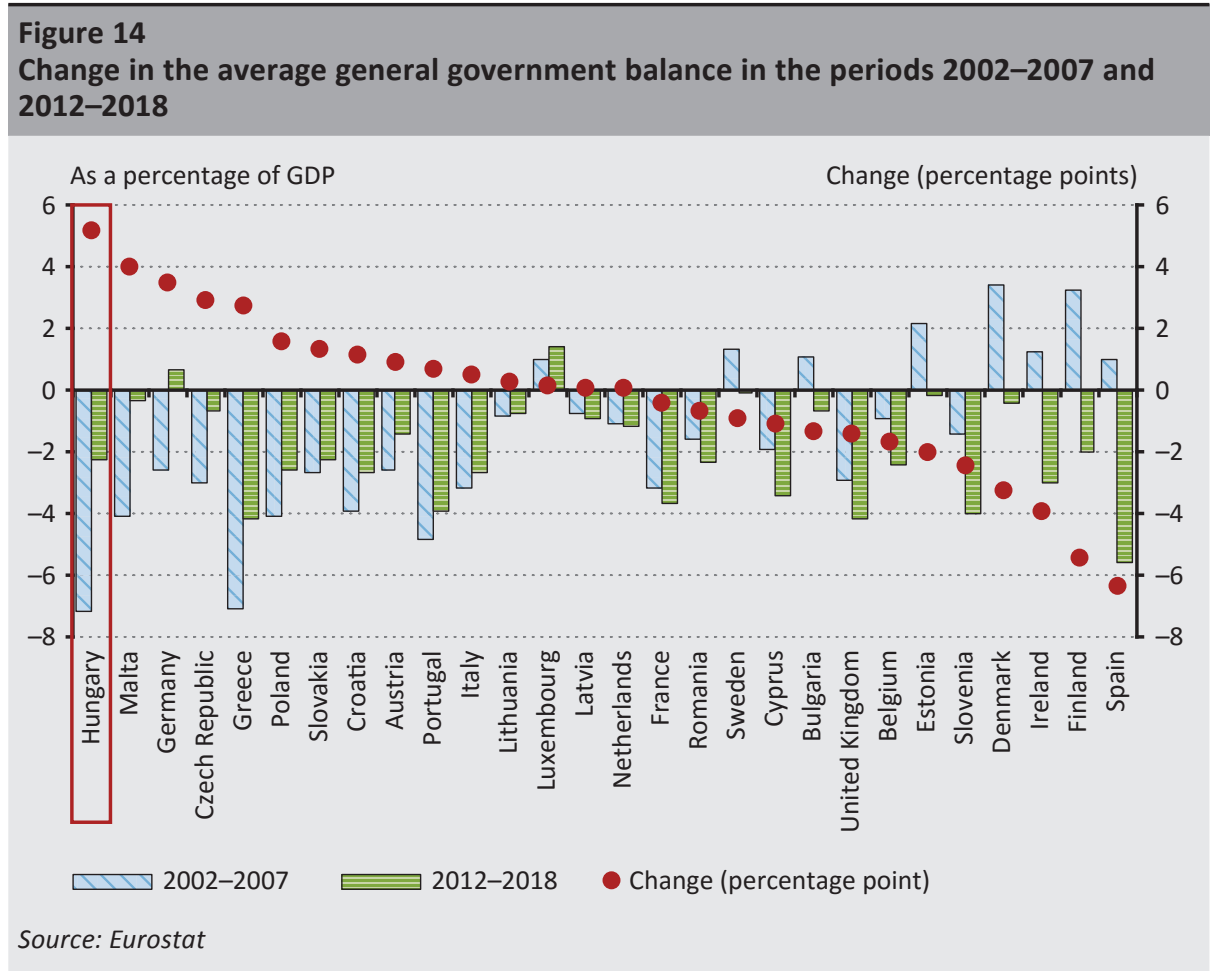

The reduction of the budget deficit was also assisted by the large-scale suppression of the shadow economy and tax evasion. Previously, tax evasion not only reduced budget revenues, but also hindered fair competition and increased uncertainty for stakeholders (e.g. unregistered employees). With a view to enhancing the efficiency of tax collection, in 2012 the government decided on the introduction of online cash registers, which was completed by 2014. The introduction of the Electronic Trade and Transport Control System (EKÁER) and the reverse VAT rates also supported more efficient tax collection. As a result of the targeted efforts, the VAT gap, i.e. the difference between the expected VAT revenue and the amount actually collected, fell from 22 per cent to 13 per cent between 2012 and 2016. The achieved level is the best among the four Visegrád countries, and Hungary moved substantially closer to the EU average in this respect as well (Figure 15). The introduction of real-time invoice reporting obligation, which came into force as of 1 July 2018, could bring another step towards reducing the hidden economy. 


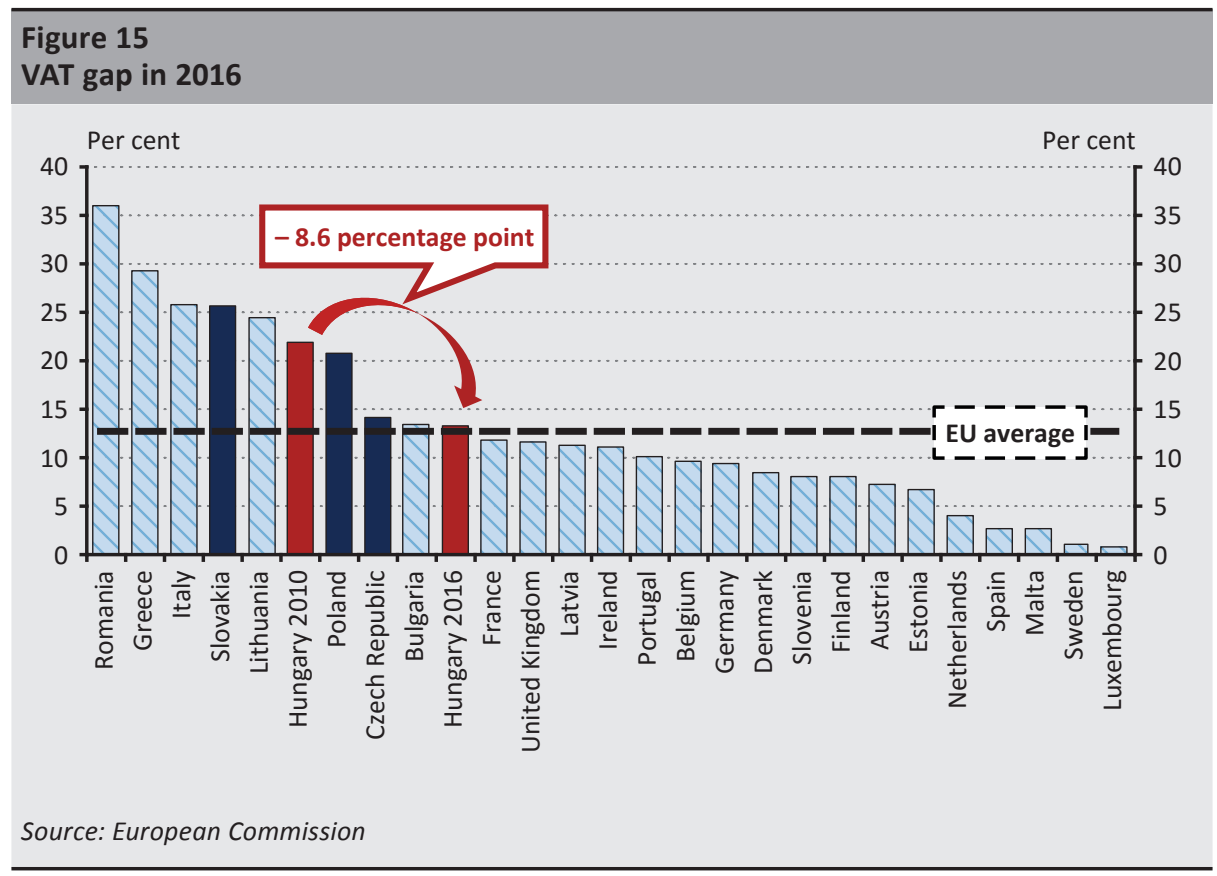

One of the most important signs of the improvement in macro financial stability is the decrease in government debt ratio, which declined substantially below the EU average. The government's commitment to this is evidenced by the fact that it elevated the objective and requirement of reducing the government debt to the constitutional level, by including it the Fundamental Law. As a result of the successful fiscal policy, the debt ratio started to decline from 2011 (Figure 16) and Hungary is the only state in the European Union, where the government debt ratio has been decreasing year by year ever since. In 2010, the Hungarian debt ratio of 80 per cent still exceeded the EU average, but by the end of 2018 it had fallen to 71 per cent (the EU average is still around 80 per cent). In parallel with the decline in government debt, the debt structure and the range of investors also changed. The MNB launched the Self-financing Programme in the spring of 2014. The primary goal of this was to increase the ratio of Hungarian funds within the financing of government debt with a view to reducing external vulnerability. Within the framework of the Self-financing Programme, the MNB diverted banks' liquid funds to the securities market, including the government securities market. The central bank's programme was instrumental in reducing the foreign currency ratio within the debt of the central budget from above 50 per cent at the end of 2011, close to 20 per cent by the end of 2018. The larger part of the government debt was also obtained by Hungarian holders: in 2011 only one-third of the debt was held by Hungarian investors, while this ratio increased to two-thirds by the end of 2018. The stable financing structure greatly contributed to the decrease in Hungary's external vulnerability, which is also reflected by the gradually improving rating of the government debt. 


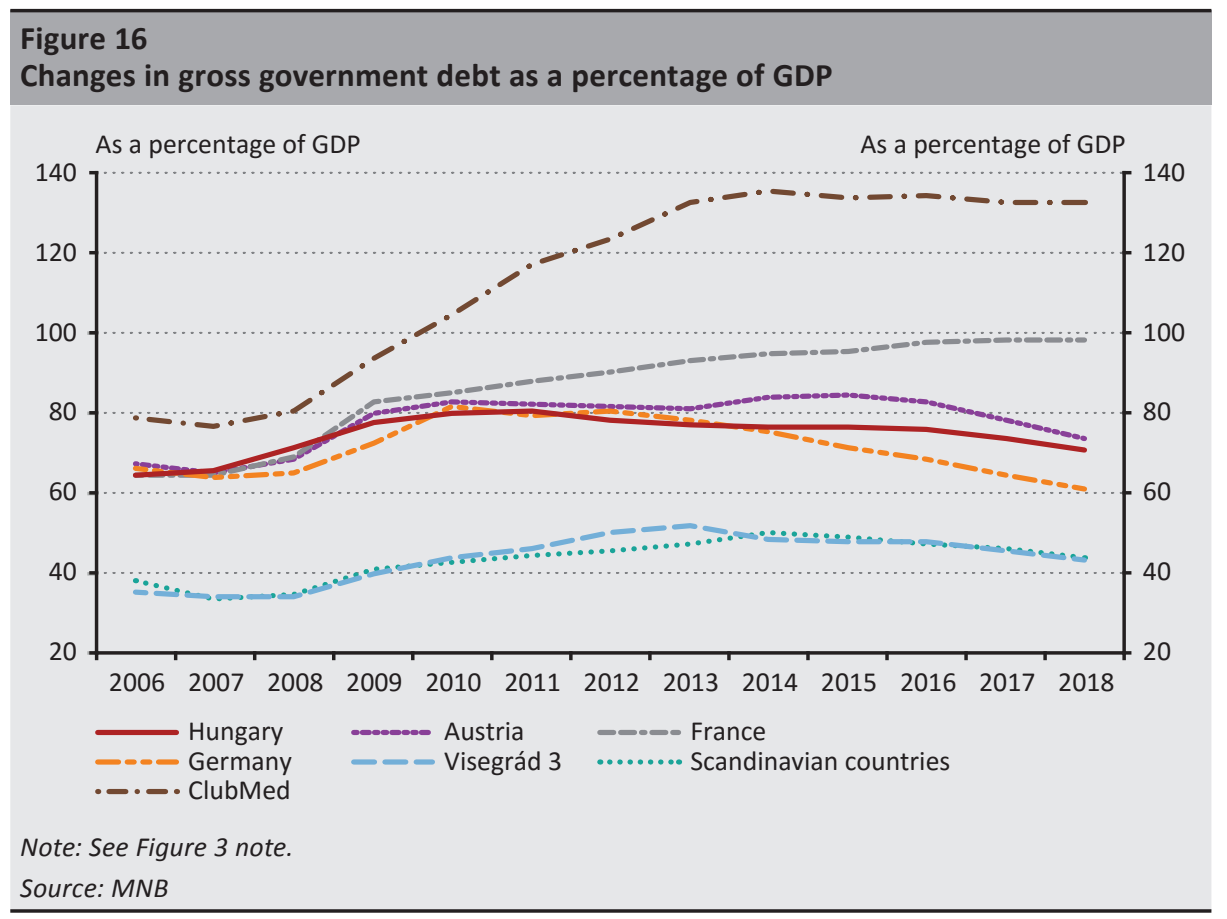

Strengthening the stability of the financial system was essential to reduce economic vulnerability. No sustainable growth exists without financial stability, and economic convergence is also unfeasible. Following the integration of the central bank and the financial supervisory authority, the MNB placed great emphasis on improving the quality of financial institutions' loan portfolios. The conversion of foreign currency loans into forint, portfolio cleaning by the credit institutions and the rise in the share of new loans disbursed under more prudent credit assessment criteria, jointly led to a gradual decrease in the ratio of non-performing loans. While in 2012 the ratio of non-performing loans was almost 20 per cent both in the household and the corporate sectors, by 2018 this ratio had fallen to below 5 per cent. This decline was outstanding in a European comparison. By 2018, of the V4 countries the ratio of the non-performing corporate loans was lower only in Slovakia (Figure 17). The strengthened balance sheets of financial institutions enable the financial intermediary system to support economic growth in the long run. 


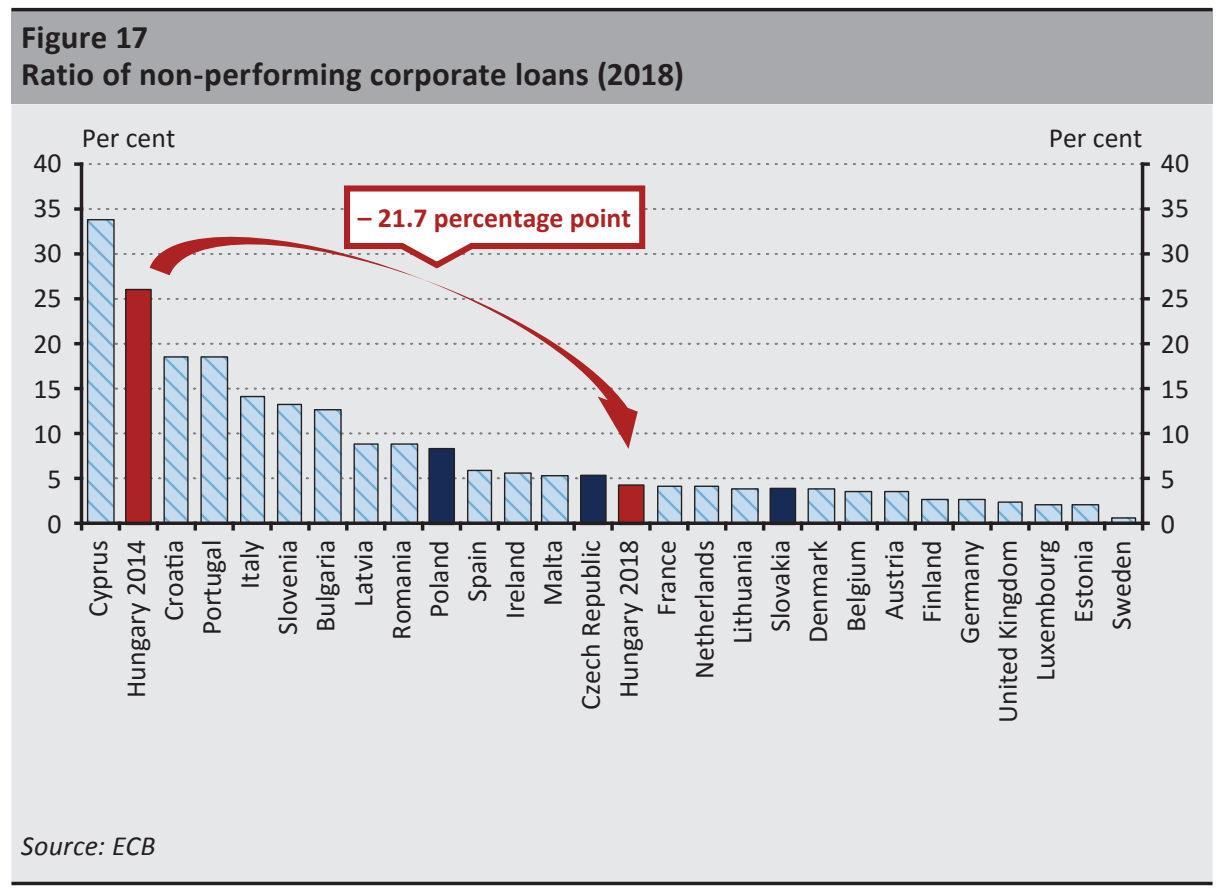

The MNB's macroprudential policy improves the stability of the financial intermediary system over the long run as well. Following the integration of financial market supervision in the central bank, the MNB has a wide-ranging set of instruments to prevent the build-up of major systemic risks. The wide set of instruments allows the MNB to respond to risks in a targeted and efficient manner.

\section{Summary and outlook}

The present period of convergence in Hungary is uniquely favourable in the history of economics. Owing to the successful crisis management implemented after 2010 and the monetary policy turnaround observed from 2013 onward, the Hungarian economy is on a growth path that maintains equilibrium. The economic growth rate exceeds the average of the European Union's advanced economies, as necessary for convergence, by at least 2 per cent (on average since 2013), and thus it is not only growth, but also convergence, which is measurable from a number of aspects. The basis of the simultaneous maintenance of equilibrium and growth is that the employment rate has already reached the EU average. As a result of the high labour demand, in recent years there was also convergence in the level of wages. Higher incomes were able to raise households' consumption and savings simultaneously, while positive economic outlook and the central bank's schemes once again raised lending to a sound level. Growth took place while maintaining, and even improving, 
equilibrium. As a result of the low budget deficit and positive current account, the government debt ratio and the external indebtedness have declined, while the structure of outstanding debt has also changed for the better.

However, the persistence and accomplishment of the convergence process is conditional on a competitiveness turnaround. The convergence period since 2013 is a major result in economic history, but continuation of this convergence should not be taken for granted. Quite on the contrary, additional efforts are needed. To date, economic growth has mostly stemmed from the rise in employment, but sustainable convergence is conditional on the activation of new growth reserves (MNB 2017b). This necessitates additional structural reforms.

The MNB supports the convergence of the Hungarian economy by analyses and proposals, in addition to other instruments. The Competitiveness Programme, published in February 2019, formulated 330 recommendations in 12 areas to ensure the development of the growth potential of the economy. The objective to see Hungary in the forefront of Europe and the world in as many areas as possible can only be achieved by brave, innovative measures. In parallel with the development of the Competitiveness Programme, the MNB strengthened its competitiveness analysis and measurement system. From autumn 2019, the central bank will examine the changes in the competitiveness of the Hungarian economy from two aspects: through the continuous monitoring of the structural measures affecting competitiveness, and through the objective measurement of the factors determining competitiveness. The MNB will present the result of such analyses in its reports, thereby also supporting the accomplishment of Hungary's competitiveness turnaround.

\section{References}

Balatoni, A. - Erdélyi, L. (2018): Nem mese az... a jelentős hazai béremelkedés tényleg megvalósult (It is not a fabrication - the major wage increase in Hungary has indeed materialised). Szakmai cikk (Article). Magyar Nemzeti Bank.

Bokor, Cs. - Endrész, M. - Fellner, Z. - Hidasi, B. - Komlóssy, L. - Lehmann, K. - Módos, D. Oláh, Zs. - Pogácsás, P. - Pellényi, G. - Plajner, Á. - Szöllősi, L. - Vadkerti, Á. - Várpalotai, V. (2014): Növekedési Hitelprogram - az első 18 hónap (Funding for Growth Scheme - the first 18 months). MNB Occasional Papers. Magyar Nemzeti Bank

Cerra, V. - Saxena, S.C. (2017): Booms, Crises, and Recoveries: A New Paradigm of the Business Cycle and its Policy Implications. IMF WP/17/250. https://doi.org/10.5089/ 9781484325759.001 
Fábián, G. - Zágonyi, Á. (2015): Átfogó segítség a megmaradt lakossági devizahitelek forintositása (Conversion of outstanding household foreign currency loans is a comprehensive assistance). Szakmai cikk (Article). Magyar Nemzeti Bank.

Fábián, G. - Pulai, Gy. (2018): A Növekedési Hitelprogram reálgazdasági hatásainak áttekintése (Overview of the real economy effects of the Funding for Growth Scheme). Szakmai cikk (Article). Magyar Nemzeti Bank.

Felipe, J. (2006): A decade of debate about the sources of growth in East-Asia. How much do we know about why some countries grow faster than others? Estudios de Economia Applicada, 24(1): 181-220.

Giday, A. - Mádi, L. (2018): A munkajövedelem adóterhelése a visegrádi térségben (Tax burden on earned income in the Visegrád region). Public Finance Quarterly, 63(3): 387-410.

Kaushik, D. (2012): Evolution of Industrial Landscape in Singapore. JTC Corporation, Singapore.

Kicsák, G. (2019): A Bundesbank módszertana szerint is jelentös a magyar költségvetés kamatmegtakaritása (The interest saving of the Hungarian budget is considerable even when calculated according to the Bundesbank methodology). Szakmai cikk (Article). Magyar Nemzeti Bank.

Kolozsi, P.P. (2018): A forintosításnak köszönhetően egy kiemelkedő stabilitási kockázattal számolt le Magyarország (As a result of the conversion of foreign currency loans into forint, Hungary fended off an outstanding stability risk). Szakmai cikk (Article). Magyar Nemzeti Bank.

Krugman, P. (1994): The myth of Asia's miracle. Foreign Affairs, 73(6): 62-78. https://doi. org/10.2307/20046929

Lehmann, K. (2019): Tényszerüen a magyar gazdaság teljesítményéről (About the performance of the Hungarian economy based on bare facts). Szakmai cikk (Article). Magyar Nemzeti Bank.

Lentner, Cs. (ed.) (2015): A devizahitelezés nagy kézikönyve (Big manual of foreign currency lending). Nemzeti Közszolgálati és Tankönyvkiadó.

Matolcsy, Gy. (2008): Éllovasból sereghajtó. Elveszett évek krónikája (From Vanguard to Bringing Up the Rear. A Chronicle of Lost Years). Éghajlat Könyvkiadó.

Matolcsy, Gy. (2015): Economic Balance and Growth. Magyar Nemzeti Bank Book Series, Kairosz Könyvkiadó Kft. 
Matolcsy, Gy. - Palotai, D. (2016): The interaction between fiscal and monetary policy in Hungary over the past decade and a half. Financial and Economic Review, 15(2): 5-32. https://en-hitelintezetiszemle.mnb.hu/letoltes/gyorgy-matolcsy-daniel-palotai-en.pdf

Matolcsy, Gy. - Palotai, D. (2018): The Hungarian Model: Hungarian Crisis Management in View of the Mediterranean Way. Financial and Economic Review, 17(2): 5-42. http://doi. org/10.25201/FER.17.2.542

Palotai, D. - Virág. B. (eds.) (2016): Competitiveness and Growth - The Road to Sustainable Economic Convergence. Magyar Nemzeti Bank.

MNB (2017a): The Hungarian Way - Targeted Central Bank Policy. Magyar Nemzeti Bank Book Series, Magyar Nemzeti Bank.

MNB (2017b): MNB Competitiveness Report. Magyar Nemzeti Bank

Nagy, M.I. (2015): Forintositás - hogy is volt ez? (Forint conversion - How did it exactly go?). Szakmai cikk (Article). Magyar Nemzeti Bank.

Palotai, D. (2017): Beértek a 2010-2013 közötti adóreform kedvezö hatásai (The favourable effects of the 2010-2013 tax reform ripened). Szakmai cikk (Article). Magyar Nemzeti Bank.

Powell, B. (2003): Economic Freedom and Growth: The Case of Celtic Tiger. Cato Journal, 22(3): 431-448.

Prammer, D. (2004): Expansionary Fiscal Consolidations? An Appraisal of the Literature on Non-Keynesian Effects of Fiscal Policy and a Case Study for Austria. Monetary Policy \& The Economy, 2004(3): 34-52.

Svraka, A. - Szabó, I. - Hudecz, V. (2014): Foglalkoztatásösztönző adókedvezmények a magyar munkaeröpiacon (Employment Stimulating Tax Incentives in the Hungarian Labour Market). Pénzügyi Szemle (Public Finance Quarterly), 58(4): 401-417.

Szoboszlai, M. - Bögöthy, Z. - Mosberger, P. - Berta, D. (2018): A 2010-2017 közötti adó- és transzferváltozások elemzése mikroszimulációs modellel (Analysis of the changes in the tax and transfer system in 2010-2017 using a microsimulation model). MNB Occasional Papers 135. Magyar Nemzeti Bank

Yoo, I. (2008): Korea's Economic Development: Lessons and Suggestions for Developing Countries. Korean Social Science Journal, 35(1): 31-63 